\title{
The rare-earth elements distribution in the Bazhenov shales
}

\author{
Ekaterina Kazak $^{1, *}$, Natalia Kharitonova ${ }^{1,2}$, and Yana Sorokoumova ${ }^{1}$ \\ ${ }^{1}$ Lomonosov Moscow State University, Hydrogeology Department, 119234, Moscow, Russian \\ Federation \\ ${ }^{2}$ Far East Geological Institute, FEB RAS, Vladivostok, Russian Federation
}

\begin{abstract}
The rare-earth elements and yttrium (REY) distribution data with depth in the Bazhenov formation are given for the case of the one well in the Nizhnevartovsk arch of the Western Siberia, Russian Federation. According to the correlation analysis, it was found that REY (mainly LREE) is concentrated in apatite more than in clays or plagioclase, while HREE is preferably accumulated in clay minerals. It was estimated that the water extracts from the Bazhenov formation contain REY up to $0.014 \mathrm{ppb}$, while LREE is contained in 3.6 times more than HREE. An attempt to estimate the REY content in the pore water of the Bazhenov formation was made using water extract composition data.
\end{abstract}

\section{Introduction}

The Bazhenov formation has a typical thickness of $15-30 \mathrm{~m}$ and is regionally spread across the entire West Siberian basin within the Russian Federation territory at depths of more than $2 \mathrm{~km}$. Despite the fact that in the reservoir water-saturated or oil-water contact zones were not found in the wells yet during the entire Bazhenov formation development period, the latest experimental studies showed that the Bazhenov formation rocks contain both free and bound water [1,2]. At the same time, the content of residual pore water is $0.42-3.65$ wt. \%.

It was published that the deposits of the Bazhenov formation are enriched with a number of trace elements and rare-earth elements and yttrium (REY) [1,3]. The REY presence in the rock matrix, as well as the fact of pore water occurrence, suggest that pore solutions should also contain REY in equilibrium concentrations with rocks.

Despite a large number of Bazhenov formation rock analytical studies, there is practically no data about their pore solution micro-component composition apart from [2]. The published work [2] presented data from the practically desalinated pore water evaporated from the Bazhenov formation rocks samples. It was discovered that a number of trace elements $(\mathrm{Li}, \mathrm{Be}, \mathrm{V}, \mathrm{Cr}, \mathrm{Co}, \mathrm{Ni}, \mathrm{Cu}, \mathrm{Zn}, \mathrm{Rb}, \mathrm{Cs}, \mathrm{U}, \mathrm{Pb}$ et al.) and $\mathrm{REY}$ content in Bazhenov formation pore water.

Currently, there are serious difficulties in the pore solution direct extraction from lowpermeable Bazhenov shales and there is no published data on the extraction and analysis of

\footnotetext{
* Corresponding author: Ekaterina@ Kazak.net
} 
directly extracted nature pore water from Bazhenov formation. Thus, the only available method for the pore solution composition investigation remains the indirect water extracting method from powdered rocks samples with natural moisture, widely used in Russian and foreign practice [4].

Nowadays, unique properties of REY are widely used for hydrogeochemistry problems both in the form of unseparated REE and in the individual elements form, due to their possibility to be geochemical markers in the determination of rocks and pore water genesis. This study was aimed to investigate the REY distribution with depth in Bazhenov formation from analyses of 5 core samples taken from the production well of the Nizhnevartovsk arch (Western Siberia, Russian Federation), also to make an assessment of REY content in the pore waters using the water extracting method from powdered rocks and oil from the same well interval. The obtained results allowed us to determine the REY concentrators in the Bazhenov formation rock and to outline their ways for entering into the water extract solutions.

\section{Sample collection and study methods}

Laboratory studies were performed on the core segments of the Bazhenov formation with the preserved nature water saturation from the one production well of the oil field located in the West Siberia Russian Federation and on the oil sample from the same well. A segment of the central part of full-size core fragment which was unaffected by drilling mud was milled and used for further researches (Fig. 1).

The X-ray-diffraction (XRD) analysis of mineral phases was completed to determine the mineral and chemical composition of the rock matrix and ICP-MS to analyze the microelements and REY contents.

In general, the water extract represents the diluted solution of the pore waters and highly soluble salts which are contained in the rock. The water extract was prepared at a weight ratio «rock or oil: distilled water» as 1:3 lasting 3 minutes. The main cations content determination in water extracts solutions was performed by inductively coupled plasma atomic emission spectrometry method by an iCAP 7600Duo spectrometer (Thermo Scientific Corporation, USA), and REE content determination - by inductively coupled plasma mass spectrometry method by an Agilent 7700 spectrometer (Agilent Techn., USA).
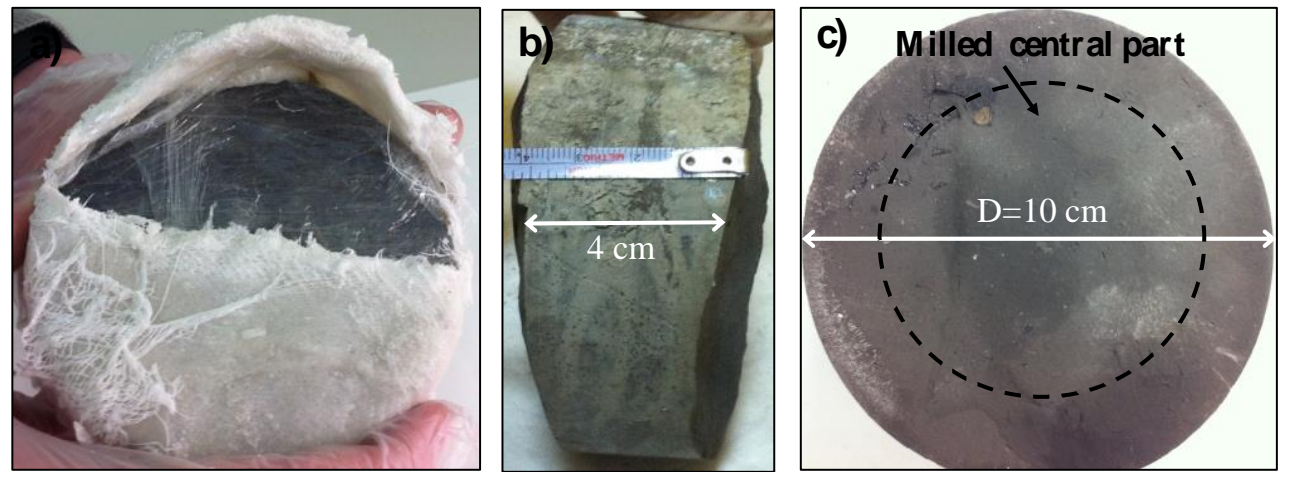

Fig. 1. Photo of the full-size core of the Bazhenov formation a) paraffinized; b,c) uncovered.

\section{Main results and discussion}

XRD analysis of bulk samples showed that quartz was the dominant mineral in the upper and lower part of the well section, with an average content of 16 to 71 wt.\% (Fig.2). The 
high content of carbonates (essentially calcite) was found at the middle part of the well 64-67 wt.\%, dolomite was present in samples S3 (5 wt.\%), and S5 (2 wt.\%). Pyrite contents are $0-13 \mathrm{wt} . \%$, apatite content decreased with depth from 6 to $0 \mathrm{wt} . \%$. Average clay content was 5 to $32 \mathrm{wt} . \%$, the hydrous micas were the dominant clay mineral. Average total organic carbon (TOC) content was 2-27 wt.\%.

It was found that Bazhenov shales have significant total REY concentration in rock (clarkes for black shales - $112 \mathrm{ppm}$ [5]) - from 110 to $173 \mathrm{ppm}$. A decrease in the REE and LREE content in the BS rocks with depth in the well was discovered, but Y and HREE concentrations increased slightly with depth (Fig.3).

The REE content in water extracts solutions from Bazhenov shales and oil was 0.69$0.024 \mathrm{ppb}$ and $0.011 \mathrm{ppb}$, respectively, with REE, LREE, HREE and Y content decreasing with depth (Fig.3). Also LREE content prevailed over HREE content in all samples (Table 1).

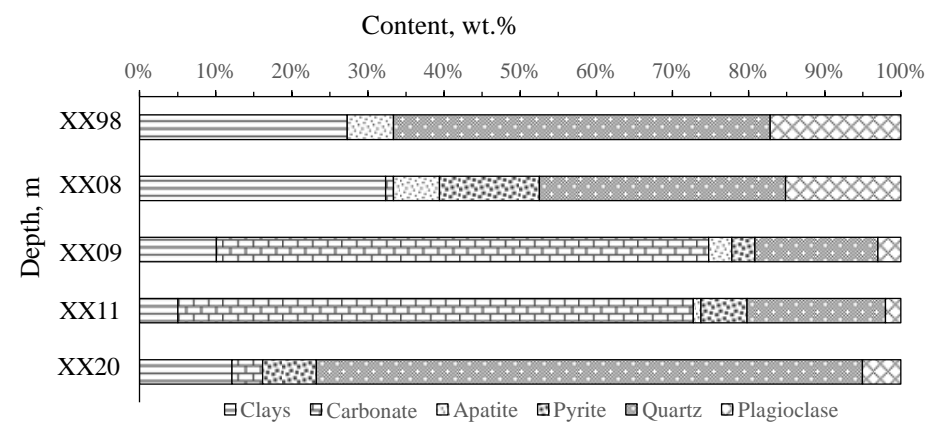

Fig. 2. XRD mineralogy of the shale samples.

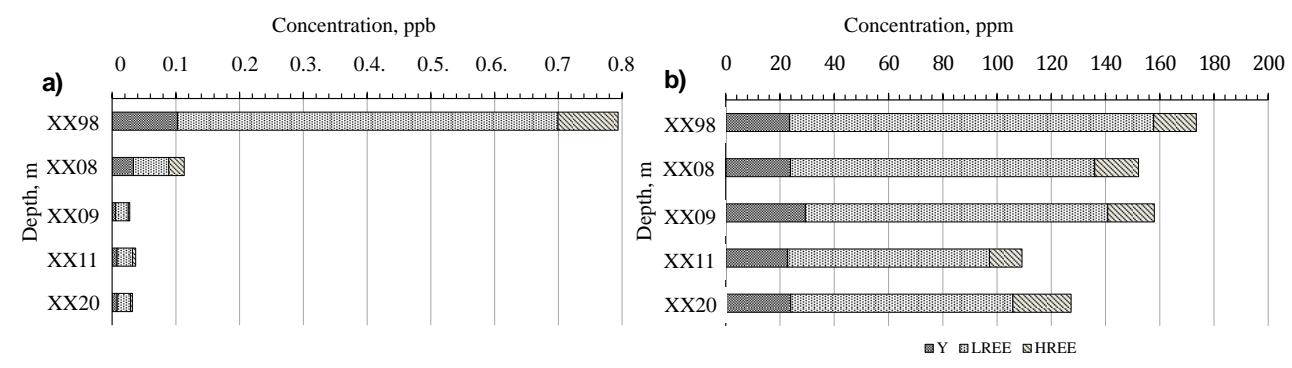

Fig. 3. Average contents of LREE, HREE and Y with depth for water extracts (a) and rocks (b)

All samples of Bazhenov formation rocks and water extracts solutions were characterized by a weak negative cerium anomaly (Table 1). A strong correlation of La, Ce and $\operatorname{Pr}$ with the content of chlorite $\left(\mathrm{r}^{2}=0.76,0.78\right.$ and 0.79 respectively), plagioclase $\left(r^{2}=0.73,0.74\right.$ and 0.74$)$ and apatite $\left(r^{2}=0.61,0.62\right.$ and 0.62$)$ was found in rocks. Such Ce anomaly for Bazhenov rocks may indicate their formation in an oxygen-containing environment. For water extract solutions, the analysis and calculation of this anomaly from the point of the pore water conditions formation is not informative, due to the fact that their preparation processed in open system conditions, in which Ce (transition valency element) was oxidized when air contacts the solution.

$\mathrm{Eu}$ shows a noticeable negative anomaly in all rock samples $\left(\log \left(\mathrm{Eu} / \mathrm{Eu}^{*}\right)=-0.10-\right.$ $0.23)$. A weak positive Eu anomaly was found for the rock sample $S 5\left(\log \left(\mathrm{Eu} / \mathrm{Eu}^{*}\right)=0.02\right)$, its cause is disputable and will be investigated in future studies.

It is interesting that for all water extract samples a strong positive Eu anomaly was found. It is possible that this is caused by the minerals dissolution during the water extracts 
preparation, although no correlation was found between the Eu content and the rock matrix mineral composition, but, at the same time, there is a correlation with the $\mathrm{Al}$ content in water extracts solutions $\left(\mathrm{r}^{2}=0.76\right)$. Aluminium has high correlation coefficients with chlorite $\left(r^{2}=0.75\right)$, plagioclase $\left(r^{2}=0.63\right)$ and apatite $\left(r^{2}=0.56\right)$.

Table 1. The REY content in the Bazhenov rock samples, shale and oil water extracts.

\begin{tabular}{|c|c|c|c|c|c|c|c|c|c|}
\hline № & Depth, $m$ & Y & REE & $\begin{array}{c}\text { LREE/ } \\
\text { HREE }\end{array}$ & Ce/Ce* & Eu/Eu* & Dy/Dy* & Nb/Nb* \\
\hline & & \multicolumn{7}{|c|}{ Water extract, ppb } \\
\hline $\begin{array}{c}\text { O } \\
1\end{array}$ & & 0.003 & 0.011 & 3.61 & -0.29 & 0.82 & -0.09 & -0.13 \\
\hline S1 & XX98 & 0.102 & 0.691 & 6.33 & -0.25 & 0.33 & -0.07 & -0.07 \\
\hline S2 & XX08 & 0.033 & 0.080 & 2.28 & -0.24 & 0.10 & -0.25 & -0.38 \\
\hline S3 & XX09 & 0.006 & 0.022 & 8.81 & -1.07 & 1.32 & -0.20 & -0.77 \\
\hline S4 & XX11 & 0.008 & 0.029 & 4.79 & -0.94 & 1.49 & -0.09 & -0.77 \\
\hline S5 & XX20 & 0.008 & 0.024 & 7.32 & -0.46 & 1.34 & -0.15 & -0.41 \\
\hline & & & & & Rock, ppm & & \\
\hline S1 & XX98 & 23.55 & 149.92 & 8.52 & -0.06 & -0.11 & -0.08 & -0.13 \\
\hline S2 & XX08 & 23.84 & 128.32 & 6.97 & -0.06 & -0.10 & -0.08 & -0.11 \\
\hline S3 & XX09 & 29.36 & 128.63 & 6.49 & -0.08 & -0.23 & -0.07 & -0.15 \\
\hline S4 & XX11 & 22.7 & 86.49 & 6.24 & -0.06 & -0.11 & -0.07 & -0.12 \\
\hline S5 & XX20 & 23.94 & 103.37 & 3.81 & -0.07 & 0.02 & -0.05 & -0.06 \\
\hline
\end{tabular}

The normalized to NASC shales graphs of REE contents in the studied Bazhenov formation show a moderate increase in contents values from LREE to HREE, whereas for water extracts there is no definite increase (Fig. 4). For samples S1, S2, S3, S4, there is the same type of normalized curves behavior, while the curve type for sample S5 is different due to the positive Eu anomaly.

Correlation analysis was used to identify the REY content relating to the Bazhenov formation rocks mineral composition. Positive correlation of LREE with hydromica $\left(r^{2}=0.83\right)$, chlorite $\left(r^{2}=0.67\right)$, plagioclase $\left(r^{2}=0.78\right)$ and apatite $\left(r^{2}=0.89\right)$ were established. At the same time, there is a strong positive correlation between Eu content and quartz content $\left(r^{2}=0.97\right)$ and also a weak correlation with the mixed-layer clay mineral content $\left(r^{2}=0.57\right)$. A positive correlation with kaolinite $\left(r^{2}=0.75\right)$ and a weak correlation with mixed-layer clay minerals $\left(\mathrm{r}^{2}=0.39\right)$ was found for HREE. In general, rocks with a high content of apatite, clays and plagioclase are most enriched with REY $\left(\mathrm{r}^{2}=0.85,0.74\right.$ and 0.76$)$. No correlation of REY content with organic matter and kerogen content was noted.

During the correlation analysis, a strong positive correlation of REY, LREE and HREE content with clay minerals were established for water extracts (especially with chlorite $r^{2}=0.78,0.77$ and 0.87 respectively), apatite $\left(r^{2}=0.61,0.60\right.$ and 0.71$)$ and plagioclase $\left(r^{2}=0.73,0.72\right.$ and 0.83$)$. Also, the correlation of REY content in water extracts and the REY content in the rock matrix $\left(r^{2}=0.72\right)$ was found.

Water extract saturation indices were calculated in the PHREEQC software package and it was determined that all solutions are undersaturated in relation to plagioclase and apatite $\left(\mathrm{SI}_{\mathrm{Pl}}\right.$ - from -1.33 to -2.41 and $\mathrm{SI}_{\mathrm{Ap}}$ - from -0.49 to -1.96$)$, which means that they can partly 
dissolve in the process of distilled water interaction with the powdered rock during the water extract preparation.

It was found that samples with apatite and plagioclase high content contain a high REY concentration. A similar result was published in the work [6] - the significant concentration of REE was observed in the Bazhenov formation interlayers with the content of apatite and fish skeleton fragments, but there was no definitive conclusion about the role of plagioclase accumulation on REE. Also in the study [6] the lowest REE content is confined to layers with high carbonate minerals content in the Bazhenov formation, in our case, this is observed for sample S4 and is not confirmed for the other four. Despite the fact that clay minerals can adsorb REY from a pore solution and, thus, accumulate them in the rock, their role compared to apatite and plagioclase for the investigated Bazhenov formation rock samples is not the dominant source.

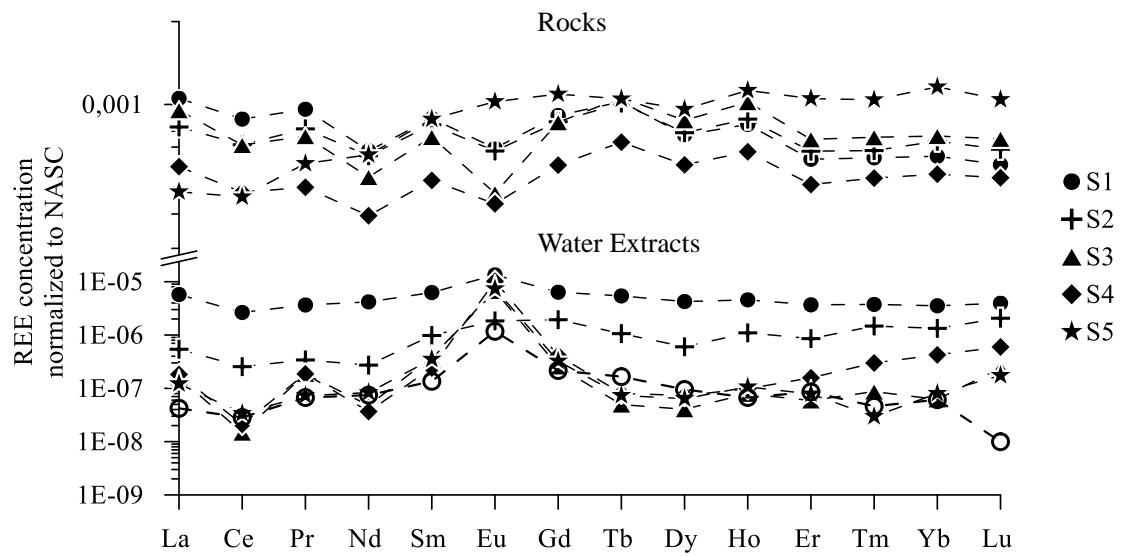

Fig. 4. REE patterns normalized to NASC.

Analysis of the water extract points out the difficulty of quantifying the REY content for rocks containing plagioclase and apatite. At the same time, despite these minerals low solubility under standard conditions, in the case of powdering, their dissolution rate increases and just 3 minutes spent on the water extract preparation is enough to saturate the solution with the REY.

The research was funded by the Russian Science Foundation grant (project № 17-77-20120).

\section{References}

1. E. Kazak, A. Kazak, M. Spasennykh, A. Voropaev, 17th Int. Mult. Scient. GeoConf. SGEM 2017, 829-841 (2017)

2. E. Kazak, N. Bogdanovich, A. Kazak , T. Mamiashev, D. Kostin, Oil Ind., 4, 48-52 (2017)

3. L. Rikhvanov, D. Usoltsev, S. Ilenok, A. Ezhova, Bull. of the Tomsk Polytech. Univ., 326(1), 50-63 (2015)

4. A. Fernández,. D. Sánchez Ledesma,C. Tournassat, A. Melón, E. Gaucher, J. Astudillo, A. Vinsot, Appl. Geoch., 49, 2-21 (2014)

5. M. Ketris, Ya. Yudovich, Int. J. of Coal Geol., 78(2), 135-148 (2009)

6. Y. Zanin, A. Zamirailova, V. Eder, V. Krasavchikov, Lithosph., 6, 38-54 (2011) 